\title{
CORRIGENDUM
}

\section{Walter Armbrust. Martyrs and Tricksters: An Ethnography of the Egyptian Revolution. (Princeton: Princeton University Press, 2019). Pp. 311 . \$27.95 cloth. ISBN 9780691162645 - Corrigendum}

Darci Sprengel

DOI: https://doi.org/10.1017/rms.2021.5; Published online by Cambridge University Press: 07 July 2021

In the initial publication of Sprengel (2021), an error occurred in the title of the book review. The correct title of the book is reproduced below:

\section{Martyrs and Tricksters: An Ethnography of the Egyptian Revolution}

The original publication has been updated to reflect this change.

\section{Reference}

SPRENGEL, D. (2021). Walter Armbrust. Martyrs and Tricksters: An Ethnography of the Egyptian Revolution. (Princeton: Princeton University Press, 2019). Pp. 311. \$27.95 cloth. ISBN 9780691162645. Review of Middle East Studies, 54(2), 352-354. doi:10.1017/rms.2021.5 